\title{
Vivien Thomas: master craftsman, gifted teacher, and unsung hero.
}

\author{
Alisha Joyner, B.S. \\ Thomas Jefferson University \\ Charles J. Yeo, MD \\ Thomas Jefferson University \\ Pinckney J. Maxwell, IV, MD \\ Medical University of South Carolina, Charleston
}

Follow this and additional works at: https://jdc.jefferson.edu/gibbonsocietyprofiles

Part of the History of Science, Technology, and Medicine Commons, and the Surgery Commons Let us know how access to this document benefits you

\section{Recommended Citation}

Joyner, B.S., Alisha; Yeo, MD, Charles J.; and Maxwell, IV, MD, Pinckney J., "Vivien Thomas: master craftsman, gifted teacher, and unsung hero." (2015). Department of Surgery Gibbon Society Historical Profiles. Paper 42.

https://jdc.jefferson.edu/gibbonsocietyprofiles/42

This Article is brought to you for free and open access by the Jefferson Digital Commons. The Jefferson Digital Commons is a service of Thomas Jefferson University's Center for Teaching and Learning (CTL). The Commons is a showcase for Jefferson books and journals, peer-reviewed scholarly publications, unique historical collections from the University archives, and teaching tools. The Jefferson Digital Commons allows researchers and interested readers anywhere in the world to learn about and keep up to date with Jefferson scholarship. This article has been accepted for inclusion in Department of Surgery Gibbon Society Historical Profiles by an authorized administrator of the Jefferson Digital Commons. For more information, please contact: JeffersonDigitalCommons@jefferson.edu. 


\title{
Vivien Thomas: Master Craftsman, Gifted Teacher, and Unsung Hero
}

\author{
ALISHA JOYNER, B.S., ${ }^{*}$ CHARLES J. YEO, M.D.,† PINCKNEY J. MAXWELL, IV, M.D.‡
}

From the *College of Medicine and the $¥$ Division of Gastrointestinal and Laparoscopic Surgery, Department of Surgery, Medical University of South Carolina, Charleston, South Carolina; and the tDepartment of Surgery, Thomas Jefferson University Hospital, Philadelphia, Pennsylvania

$\mathrm{T}$ HE FIELD OF PEDIATRIC cardiovascular surgery gained international recognition in 1944 with the first successful correction of a tetralogy of Fallot congenital anomaly in a 15 -month-old patient. Dr. Helen Taussig (1898 to 1986), a pediatrician at Johns Hopkins Hospital, recognized the need for the procedure. Dr. Alfred Blalock (1899 to 1964), Chief of Surgery at Johns Hopkins Hospital, is credited with performing the surgery. However, there is an unsung hero who for many years did not receive a single mention in the medical literature. Vivien Thomas (1910 to 1985) was Dr. Blalock's research assistant who is said to have stood directly behind him during the "blue baby" procedures, providing Dr. Blalock with support and advice. $^{1}$

\section{Vivien Thomas}

Vivien Thomas was born in New Iberia, Louisiana, during a time of racial unrest. While Thomas was still a young child, his family relocated to Nashville, Tennessee. $^{2}$ As a result of U.S. segregation laws, Thomas attended Tennessee Agricultural and Industrial State College, one of the few institutions that admitted black students. He enrolled in 1929 with ambitions of becoming a physician. Unfortunately, the Great Depression caused the collapse of the banking system where Thomas' savings were kept. Thomas was only able to complete one semester of college before his funding ran out. With no money for tuition, Thomas' dream to become a physician was put on hold. He withdrew from school and began looking for work. ${ }^{1}$ In 1930, following the suggestion of a friend, Thomas applied for a position at Vanderbilt University in Dr. Alfred Blalock's laboratory and was hired immediately (Fig. 1). ${ }^{2}$

Address correspondence and reprint requests to Pinckney J. Maxwell, IV, M.D., Assistant Professor of Surgery, Colon and Rectal Surgery, Medical University of South Carolina, Ashley River Tower, 25 Courtenay Drive, Suite 7100A, Charleston, SC 29425. E-mail: maxwelpj@musc.edu.
Alfred Blalock

Alfred Blalock was born in Culloden, Georgia. In 1922, he graduated from the Johns Hopkins School of Medicine where he remained for an internship in urology because his academic performance was not considered sufficiently proficient for an internship in surgery. After only a few months of hard work, Dr. Blalock was offered a position in the general surgery program by Dr. John M. T. Finney, who became the acting Chief of Surgery after the death of Dr. William S. Halsted. Dr. Blalock later resigned from the general surgery program and entered the otolaryngology program although the specific details of why are unclear. In 1925, after several years in different programs, Dr. Blalock left Johns Hopkins with intentions of studying in Boston. Dr. Blalock actually moved to Boston with plans to enter the general surgery program at Brigham and Women's Hospital. He never had the chance to unpack his bags in Boston. Adhering to the advice of his close friend, medical school roommate, and future author of internal medicine's most authoritative textbook, Dr. Tinsley Harrison, Dr. Blalock moved to Nashville, Tennessee, to enter the newly established general surgery residency program at Vanderbilt University Hospital. After completing the program at Vanderbilt, Dr. Blalock remained on as faculty. By 1938 he attained the status of full Professor and was given his own animal research laboratory. ${ }^{2}$ The faculty appointment occupied most of Dr. Blalock's time so he was forced to find additional help in the laboratory. ${ }^{1}$

\section{Thomas and Blalock's Collaborations}

Hiring Vivien Thomas proved to be a brilliant and fruitful decision, because Thomas was a fast learner and quickly became a valuable asset to the laboratory. Often, Thomas conducted experiments alone and reported his results directly to Dr. Blalock after verifying them several times. For certain experiments, Thomas designed the tools necessary to complete the experiment when they were not available. One such tool was the vascular clamp (Fig. 2) that Thomas 


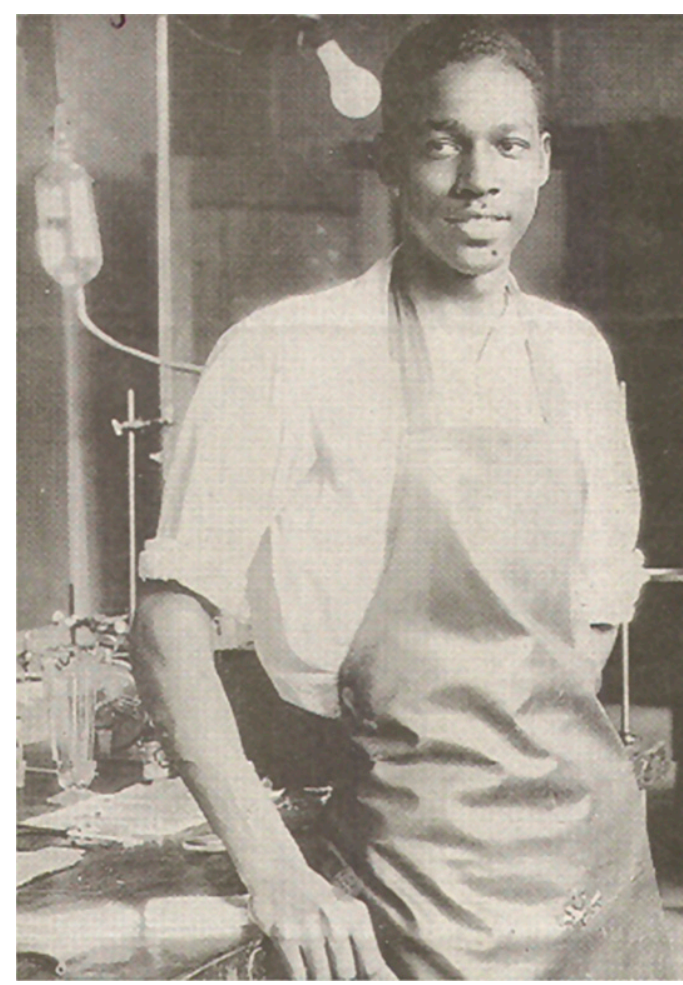

FIG. 1. Vivien Thomas (1910 to 1985). Available at: www 3quarksdaily.com/3quarksdaily/2011/02/a-surgical-assistant-withhands-blessed-by-god-vivien-thomas.html. Accessed May 18, 2013.

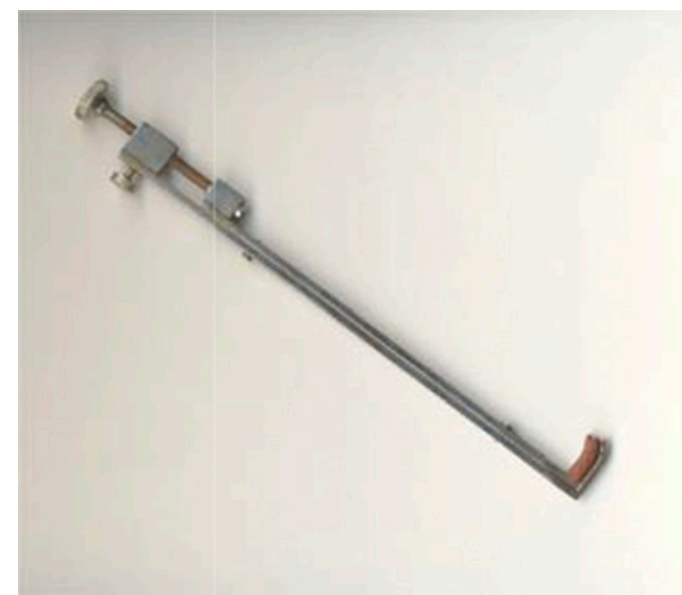

FIG. 2. Vascular clamp designed by Vivien Thomas and William Longmire. Available at: www.medicalarchives.jhmi.edu/ clampbg.jpg. Accessed May 18, 2013.

designed in collaboration with Dr. William Longmire. ${ }^{2}$ Thomas also assisted William Kouwenhouven, an electrical engineer, in the production of the electrical cardiac defibrillator. ${ }^{1}$

Together Dr. Blalock and Thomas used animal models to investigate the hemodynamic causes and sequelae of traumatic hemorrhagic shock. They concluded that excessive intravascular blood loss led to traumatic shock. Their groundbreaking research proved to be critical in saving the lives of countless soldiers in World War II by providing the groundwork for treatment of the wounded. ${ }^{1}$ At Dr. Blalock's request, Thomas created a subclavian artery to pulmonary artery end-to-end anastomosis to serve as a model of pulmonary hypertension. Although the model was unsuccessful, it served as excellent experience for upcoming innovations. Thomas' work also included the simulation of pulmonic valvular stenosis in dogs through application of nitric acid to the valve cusps. ${ }^{3}$

Dr. Blalock and Thomas worked together at Vanderbilt for over 10 years; however, Thomas' name was never included in any of his publications. Dr. Blalock turned down a Chair position at Henry Ford Hospital in Detroit when they refused to allow Thomas to accompany him because Thomas was black. ${ }^{2}$ This is evidence that Dr. Blalock recognized Thomas as an intricate part of his work. In 1941, Blalock was offered the position of Chief of Surgery at Johns Hopkins, but he only accepted the offer when Hopkins agreed that Thomas could accompany him to Baltimore. ${ }^{2}$

\section{Helen Taussig}

Dr. Helen Taussig, Director of the Johns Hopkins Harriet Lane Home, spent her entire career diagnosing pediatric congenital cardiac diseases. She was limited by the number of diagnostic tools available, so she relied on her history-taking and physical examination skills to help identify and differentiate between cardiac lesions. Dr. Taussig noticed that patients with tetralogy of Fallot developed cyanosis except in the cases where patients also had a patent ductus arteriosus (PDA). She noted that when the PDA was closed, these patients then developed cyanosis. ${ }^{4}$ In August of 1938, Dr. Robert Gross, a surgeon at Children's Hospital in Boston, successfully ligated a PDA. ${ }^{2,5}$ This surgery motivated Dr. Taussig to travel to Boston and meet with Dr. Gross to discuss the prospects of creating an arterial duct that would reroute more blood to the lungs in patients with tetralogy of Fallot to counteract the cyanosis caused by the anomaly. However, having just discovered a way to repair patent ductuses, he was in no way interested in actually creating ductuses.

Dr. Taussig subsequently returned to Baltimore, but she did not give up her idea. In 1943, Dr. Edwards A. Park, Chairman of Pediatrics at Johns Hopkins, invited Dr. Alfred Blalock to give a presentation to the Department of Pediatrics on Dr. Blalock's experiments to relieve aortic coarctation. ${ }^{1}$ Afterward Dr. Taussig discussed with Dr. Blalock her dilemma in treating cyanotic patients. Dr. Blalock organized a meeting with Dr. Taussig and Vivien Thomas during which Dr. Taussig displayed her research on tetralogy of Fallot defects. Dr. Blalock sensed Dr. Taussig's frustration 


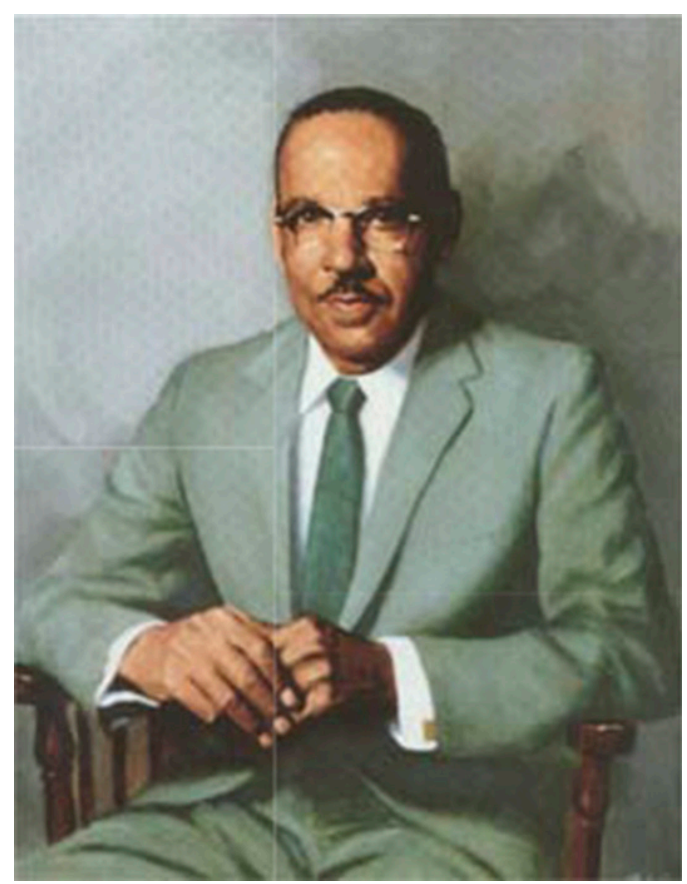

FIG. 3. Vivien Thomas' portrait in the Blalock Building, first floor lobby. Available at: www.medicalarchives.jhmi.edu/vtcllg.jpg. Accessed May 18, 2013.

and appreciated her dedication to the field. In previous research attempting to replicate the physiologic effects of pulmonary arterial hypertension, Dr. Blalock and Thomas had proposed an artificial ductus system, so Dr. Taussig's idea was quite intriguing to Dr. Blalock. ${ }^{5}$

\section{Blalock-Taussig Shunt}

At Dr. Blalock's suggestion, Vivien Thomas developed the subclavian artery to ipsilateral pulmonary artery shunt, ${ }^{4}$ which was later named the BlalockTaussig shunt. Anna, the dog, was Thomas' first success and survivor of the procedure. ${ }^{3}$ Once Thomas perfected the procedure, the plan was for Dr. Blalock to assist Thomas with the procedure several times and then conduct it on his own. Unfortunately, Dr. Blalock only assisted Thomas once before he was called to the operating room for a patient in critical condition. November 29, 1944 was the first time the Blalock-Taussig shunt was performed on a human. ${ }^{3}$ The patient was a 15-month-old girl named Eileen Saxon who had been born with a tetralogy of Fallot malformation. She weighed only $4.5 \mathrm{~kg}$. ${ }^{1,4}$ The procedure was so risky that the Chief of the Division of Anesthesiology, Dr. Austin Lamont, refused to anesthetize the patient. He did not want to take part in what he believed would be the death of a child. ${ }^{4}$
The day of the procedure Vivien Thomas helped to prepare the operating room, making sure all the necessary equipment to perform the surgery was readily available. Thomas then returned to the laboratory awaiting the end of the operation. While in the laboratory, Thomas received notice that Dr. Blalock had requested his presence. Thomas made his way to the observation theater above the operating room with the other spectators. When Dr. Blalock noticed Thomas overhead but in the theater, he motioned for him to come into the operating room and stand on a stool he had placed directly behind him. ${ }^{1}$ Throughout the entire procedure, Blalock would turn to Thomas for recommendations and his nod of approval. The operation was successful, but unfortunately Eileen died 6 months later after a second operation. ${ }^{4}$ Thomas was present for the next several procedures that were all successful. In 1945, Dr. Blalock published a report in the Journal of the American Medical Association describing the first three patients to receive the Blalock-Taussig shunt. ${ }^{1}$ Although Vivien Thomas was instrumental in the development and success of these procedures, he was not mentioned in the report; only Alfred Blalock and Helen Taussig received recognition.

\section{Vivien Thomas}

Clearly, Vivien Thomas was a master craftsman, gifted teacher, and an unsung hero.

Throughout his career, Thomas was charged with the training of many of the great surgeons in history, including supervising the surgical animal laboratory for generations of surgery residents at Johns Hopkins. Unfortunately, Thomas never received his due recognition nor was he ever recognized as a physician. In 1976 Johns Hopkins University awarded Thomas with an honorary degree of Doctor of Law. ${ }^{2,3}$ Thomas' portrait (Fig. 3) hangs in the Alfred Blalock Building on the campus of Johns Hopkins University Hospital. Vivien Thomas is noted as the only nonchairman given the honor to adorn the Blalock Lobby. ${ }^{3}$

\section{REFERENCES}

1. Brogan TV, Alfieris GM. Has the time come to rename the Blalock-Taussig shunt? Pediatr Crit Care Med 2003;4:450-3.

2. Evans W. The Blalock-Taussig shunt: the social history of an eponym. Cardiol Young 2009;19:119-28.

3. Cheng T. Hamilton Naki and Christiaan Barnard versus Vivien Thomas and Alfred Blalock: similarities and dissimilarities. Am J Cardiol 2006;97:435-6.

4. Baum V. Pediatric cardiac surgery: an historical appreciation. Paediatr Anaesth 2006;16:1213-25.

5. Waldhausen J. The early history of congenital heart surgery: closed heart operations. Ann Thorac Surg 1997;64:1533-9. 